\title{
ПРИЧИНИ ПРАВОПОРУШЕНЬ АКАДЕМІЧНОЇ ДОБРОЧЕСНОСТІ В ЗАКЛАДАХ ВИЩОЇ ОСВІТИ
}

\author{
Рябенко М. I. \\ кандидат педагогічних наук, дочент, \\ доиент кафедри педагогіки \\ Одеський національний університет імені I. І. Мечникова \\ вул. Франиузький бульвар, 24/26, Одеса, Україна \\ orcid.org/0000-0001-7105-6683 \\ mykhailr@ukr.net
}

\author{
Ключові слова: учасники \\ освітнього процесу, \\ відповідальність, соиіальна \\ норма, норма права, чинники, \\ обставини.
}

Статтю присвячено проблемі правопорушень академічної доброчесності у закладах вищої освіти України. Зокрема, аналізуються основні причини, що спричиняють відповідне діяння.

У статті висвітлено сутність поняття «академічна доброчесність» та відповідно те, що вважається порушенням академічної доброчесності та до якої відповідальності можуть притягнути основних учасників освітнього процесу у відповідності до чинного законодавства. Визначено сутність поняття «правопорушення» та тлумачення поняття «причина». У ході дослідження виявлено, що порушення норм академічної доброчесності в закладі вищої освіти являють собою складний причинний комплекс, що включає безліч різноманітних за змістом, характером, часом і місцем тощо чинників. Проаналізовані основні суб'єктивні та об'єктивні чинники, що спонукають учасників освітнього процесу до порушення правових норм щодо дотримання стандартів академічної доброчесності під час навчальної та наукової діяльності у закладі вищої освіти. До суб' єктивних чинників належать обставини, що залежать від учасників освітнього процесу закладу вищої освіти: духовно-моральний рівень, мотиви зайняття відповідною діяльністю, небажання працювати, низький рівень правосвідомості, невміння провадити наукові дослідження тощо. До об'єктивних чинників належать обставини, які не залежать від учасників освітнього процесу: відповідні суперечності в колективі, соціальне становище, незадовільний рівень матеріально-технічного забезпечення тощо. Чинники об'єктивно-суб'єктивного характеру, які лише певною мірою залежать від конкретного учасника освітнього процесу: внутрішня дисципліна, відсутність належного відбору на посади наукових та науково-педагогічних працівників, зокрема щодо етичного рівня, недостатня поінформованість учасників освітнього процесу щодо вимог норм чинного законодавства щодо стандартів академічної доброчесності, неналежний контроль керівництва відповідних підрозділів та органів управління закладом вищої освіти, вимога формальних кількісних показників (публікацій, методичного забезпечення тощо). 


\title{
THE CAUSES OF ACADEMIC INTEGRITY VIOLATIONS IN HIGHER EDUCATION INSTITUTIONS
}

\author{
Ryabenko M. I. \\ Candidate of Pedagogical Sciences, Associate Professor, \\ Associate Professor at the Department of Pedagogy \\ Odessa I. I. Mechnikov National University \\ Frantsuzkyi bulvar str., 24/26, Odessa, Ukraine \\ orcid.org/0000-0001-7105-6683 \\ mykhailr@ukr.net
}

Key words: participants of educational process, responsibility, social norm, rule of law, factors, circumstances.
The article is dedicated to solving the problem of academic integrity violations in higher education institutions of Ukraine. In particular, the fundamental causes that lead to such actions are analyzed.

The article covers the essence of the concept of "academic integrity" and, thereafter, what is considered to be a violation of academic integrity and what responsibility the main participants of the educational process can be brought to in accordance with the current legislation. The essence of the concept of violation and the interpretation of the notion of cause are highlighted. During the study, it was revealed that academic integrity violation in higher education institutions is a complicated causal complex that includes a variety of factors, in terms of content, nature, time and place, etc. The main subjective and objective factors that encourage the participants of the educational process to violate the legal norms concerning the observance of the standards of academic integrity during the educational and scientific activity in the higher education institution are determined. Subjective factors include circumstances that depend on the participants of the educational process in higher education institution: spiritual and moral level, some motives for engaging in appropriate activities, unwillingness to work, low level of legal consciousness, lack of ability to carry out the research, etc. Objective factors involve circumstances that do not depend on the participants of the educational process: relevant contradictions in the team, social situation, unsatisfactory level of financial and technical support, etc. Factors of objective and subjective nature that depend on a particular participant of the educational process only to a certain extent: provision, internal discipline, lack of proper selection for the post of scientific and educational workers, including the ethical level: lack of awareness of the participants of the educational process concerning the requirements of the current legislation on the standards of academic integrity, incompetent control of the management bodies of relevant departments and governing bodies of higher education institution, the requirement for formal quantitative indicators (publications, methodological support, etc.).
Постановка проблеми. На сучасному етапі розвитку нашої країни перед вищою школою стоять актуальні завдання забезпечення потреб суспільства та держави кваліфікованими фахівцями. У контексті входження України до загальноєвропейського простору вищої освіти поряд 3 проблемою ефективних шляхів формування особистості професіонала і громадянина у сучасних конкурентних ринкових умовах перед закладами вищою освіти особливої значущості набула проблема якості підготовки фахівця, зокрема пору- шення учасниками освітнього процесу правових норм щодо дотримання академічної доброчесності. У зв'язку з цим успішне вирішення завдання щодо попередження та протидії правопорушень академічної доброчесності в закладах вищої освіти, на наш погляд, неможливе без виявлення та дослідження основних причин цього діяння.

Аналіз останніх досліджень і публікації. Аналіз опрацьованої літератури дав можливість наголосити, що проблему причин правопорушень досліджують вітчизняні та закордонні вчені 
різних галузей знань: правознавці, психологи, соціологи, економісти, педагоги тощо. Серед них -Ю. Александров, Д. Аріелі, В. Васильєв, I. Даньшин, О. Джужа, А. Долгова, Н. Дубінін, $€$. Іллін, М. Корнієнко, К. Ломбросо, В. Лунєєв, Н. Максимова, І. Мельник, В. Романюк, О. Скакун, О. Федоренко, Х. Шнейдер та інші.

Нині потрібно констатувати зростання зацікавленості вирішенням проблеми порушення норм академічної доброчесності. Серед закордонних дослідників можна відзначити праці таких учених, як: Д. Вілсон, Н. Кіохей, Е. Кіс, С. Коул, Д. Макдафф, Д. МакКей, Г. Повелла, Б. Уитли, Т. Фолтинек, Л. Хінман, К. Шпигель та інші. Аналіз вітчизняних праць дозволяє стверджувати, що проблема дотримання академічної доброчесності в закладах освіти $є$ актуальною та досліджується такими науковцями, як: В. Андрущенко, П. Артемов, А. Артюхов, К. Афанасьєва, В. Бакіров, В. Буряк, О. Габович, О. Гончарова, О. Гужва, С. Дикань, М. Дойчик, I. Сгорченко, К. Ковальчук, М. Крук, В. Кузнєцов, М. Литвин, А. Мельниченко, Н. Миронець, О. Полоцька, I. Порало, А. Рапопорт, О. Рижко, Н. Семенова, А. Слива, М. Серебряков, Л. Сокурянська, Н. Стукало, В. Троцька, Т. Фініков, Н. Шліхта, І. Шліхта, А. Штефан, та іншими.

Метою статті $\epsilon$ аналіз основних причин правопорушень академічної доброчесності в закладах вищої освіти.

Виклад основного матеріалу дослідження. Історія розвитку відносин у суспільстві засвідчує, що свідомо чи несвідомо кожна людина у своїй діяльності керується певними правилами або нормами. Одними з видів соціальних норм, що регулюють найважливіші відносини у суспільстві, $\epsilon$ норми права. На відміну від інших видів соціальних норм, норми права є загальнообов'язковими правилами поведінки, що офіційно закріплюються та забезпечуються державою $з$ метою встановлення і підтримки порядку. Винне діяння, що порушує правову норму, в юриспруденції визначається як правопорушення, за яке особа може понести юридичну відповідальність. Основними нормами права, що регулюють діяльність закладів вищої освіти в Україні, є Конституція України та відповідно Закон України «Про освіту» та Закон України «Про вищу освіту» тощо.

Так, у відповідності до Закону України «Про освіту» одними із засад державної політики у сфері освіти нашої країни та принципами іiі освітньої діяльності є академічна доброчесність, яка визначається як сукупність етичних принципів та визначених законом правил, якими мають керуватися учасники освітнього процесу під час навчання, викладання та провадження наукової діяльності з метою забезпечення довіри до резуль- татів навчання та наукових досягнень. Зокрема, для науково-педагогічних працівників та здобувачів закладу вищої освіти дотримання академічної доброчесності передбачає: посилання на джерела інформації у разі використання ідей, тверджень, відомостей тощо; дотримання норм законодавства про авторське право і суміжні права тощо. Для науково-педагогічних працівників також необхідно здійснювати об'єктивне оцінювання результатів навчання здобувачів, контролювати дотримання академічної доброчесності здобувачами освіти тощо. Відповідно, порушенням академічної доброчесності, згідно із чинним законодавством, визнається: академічний плагіат; самоплагіат; фабрикація; фальсифікація; списування; обман; хабарництво; необ'єктивне оцінювання тощо. За скоєння таких порушень науково-педагогічні працівники можуть бути притягнуті до відповідальності: відмові у присудженні наукового ступеня чи присвоєнні вченого звання або позбавлення вже набутих ступенів та звань тощо. За порушення норм академічної доброчесності здобувачі освіти також можуть бути притягнуті до академічної відповідальності: повторне проходження оцінювання, відрахування із закладу освіти, позбавлення стипендії тощо [7].

3 точки зору формального підходу на законодавчому рівні поняття академічної доброчесності, види правопорушень та відповідна відповідальність визначені та встановлені. Водночас, як засвідчують наші спостереження, рівень порушень академічної доброчесності, зокрема у закладах вищої освіти, суттєво не зменшується. За даними опитування студентів закладів вищої освіти Одеси, близько 90\% респондентів у своїй діяльності стикаються 3 порушеннями академічної доброчесності. Як і будь-яке правопорушення, порушення норм закону щодо академічної доброчесності має свої причини. Зокрема, давньогрецький лікар і філософ Гіппократ зазначав, що «нічого не відбувається без причини. Якщо щось сталося, то можна бути впевненими, що для цього була причина». Аналіз літератури дав змогу стверджувати, що слово «причина» визначається як явище, яке зумовлює або породжує інше явище, а також підстава, привід для яких-небудь дій, вчинків або спонукання, міркування, мотиви, якими викликаються які-небудь вчинки, обставина, чинник тощо $[4$, с. $555 ; 8$, с. 469]. У нашому дослідженні під причинами правопорушень академічної доброчесності ми будемо розуміти чинники та обставини, що спонукають особу до вчинення діяння (дії або бездіяльності) щодо порушення норм права, якими мають керуватися учасники освітнього процесу під час навчання, викладання та провадження наукової діяльності. Аналізуючи основні причини правопорушень академічної 
доброчесності в закладах вищої освіти, вважаємо за доцільне наголосити на тому, що вони являють собою складний комплекс, який включає безліч різноманітних за змістом, характером, часом i місцем чинників та обставин. Як зазначав Галілео Галілей: «Усі істини легко зрозуміти, щойно їх виявлено; та спершу треба їх виявити» [1, с. 112].

Для зручного огляду всіх причин за основу у нашому дослідженні ми взяли класифікацію причин правопорушень відомого професора О. Скакун. Відповідно, всі причини правопорушень академічної доброчесності у закладах вищої освіти ми класифікували на чинники та обставини об'єктивного та суб'єктивного характеру, а також об'єктивно-суб'єктивного характеру. До об'єктивних ми віднесли: чинники та обставин, які не залежать від конкретного учасника освітнього процесу: відповідні суперечності в колективі, соціальне становище, незадовільний рівень матеріально-технічного забезпечення тощо. До суб'єктивних належать чинники та обставини, що залежать від конкретної особи: духовно-моральний рівень учасника освітнього процесу, мотиви відповідної діяльності, небажання працювати або навчатись, низький рівень правосвідомості, невміння здійснювати наукові дослідження тощо. Чинниками та обставинами об'єктивно-суб'єктивного характеру ми визначили ті, які лише певною мірою залежать від конкретного учасника освітнього процесу: внутрішня дисципліна, відсутність належного відбору на посади наукових та науково-педагогічних працівників, зокрема щодо етичного рівня, недостатня поінформованість учасників освітнього процесу щодо вимог норм чинного законодавства, щодо стандартів академічної доброчесності, неналежний контроль керівництва відповідних підрозділів та органів управління закладом вищої освіти, вимоги щодо формальних кількісних показників (публікацій, методичного забезпечення тощо).

Одним 3 найсуттєвіших об'єктивних чинників, що спонукає учасників освітнього процесу до вчинення правопорушень академічної доброчесності, $\epsilon$ недостатній економічний розвиток України, який суттєво вплинув на ефективну діяльність закладів вищої освіти. Як наслідок, для суспільства і системи освіти значущою постала проблема корупції, яка в нашій країни набула системного характеру і здебільшого замінила офіційні правові відносини. Корупційні діяння підірвали у суспільстві авторитет державних інституцій загалом та закладів вищої освіти зокрема, зруйнували відчуття справедливості, захисту прав та стабільного розвитку. Також неможливість учасників освітнього процесу задовольнити елементарні потреби та інші обставини матеріально-побутового забезпечення діяльності ЗВО суттєво знижують рівень цінніс- них орієнтацій, переконань, життєвих позицій та мотивів учасників освітнього процесу, що має насідком корисливе ставлення до своєї діяльності, ослаблення контролю за виконанням правових норм загалом та правил академічної доброчесності зокрема. У цьому контексті доречне латинське прислів'я "necessitas non habet legem" - «необхідність не признає законів». До об'єктивних причин порушення академічної доброчесності у 3ВО можна також віднести певні прогалини в законодавстві та не досить регламентований механізм притягнення винних до відповідальності за порушення норм академічної доброчесності. Наприклад, у судовому порядку майже неможливо доказати більшість порушень академічної доброчесності (зокрема, плагіат) та скасувати минулі рішення вже неіснуючих інстанцій тощо.

Серед суб'єктивних причин правопорушень академічної доброчесності у ЗВО, що залежать від конкретного учасника освітнього процесу, вважаємо доцільним виокремити низький духовно-моральний рівень учасників освітнього процесу, зокрема науково-педагогічних працівників, які належать до безпосередніх суб'єктів формування академічної доброчесності у закладах вищої освіти. Зокрема, за нашими дослідженнями близько 97\% учасників освітнього процесу закладів вищої освіти Одеси вважають наявність у науково-педагогічних працівників морально-етичних цінностей необхідною. Як ми зазначали, одним 3 обов'язків науково-педагогічних працівників є здійснення об'єктивного оцінювання результатів навчання здобувачів та контроль за дотриманням академічної доброчесності здобувачами освіти. Зокрема, наші дослідження виявили, що лише близько $10 \%$ студентів вважають об'єктивними оцінювання в $100 \%$ випадків. Водночас Закон України «Про вищу освіту» встановлюе основними вимогами на посаду науково-педагогічного працівника лише наявність наукового ступеня або вченого звання чи ступеня магістра. Тобто законодавець не вважає необхідність перевіряти на наявність доброчесності у того, хто вже завтра зобов' язаний буде формувати та перевіряти доброчесність в інших. Дуже доцільне для нашого часу твердження К. Ушинського: «Добре міркувати про чесноту - ще не означає бути доброчесним» [3, с. 220]. Доцільне твердження сучасного вченого I. Подласого: «Знання без морального сенсу - меч у руках божевільного» [6, с. 15]. Натепер сучасним закладам вищої освіти потрібні науково-педагогічні працівники, які своїм прикладом зможуть допомогти сформувати цінності, погляди та принципи академічної доброчесності серед учасників освітнього процесу. Як зазначав відомий педагог Я. Коменський, «легко слідувати правильно за тим, хто правильно йде попереду». 
Від належного духовно-морального рівня, зокрема науково-педагогічних працівників, багато в чому залежать мотиви діяльності учасників освітнього процесу. Ще Л. Толстой стверджував, що «головною перешкодою пізнання істини є не брехня, а подібність істини» [5, с. 114]. Однією з важливих причин правопорушень академічної доброчесності, на наш погляд, також $€$ невміння здійснювати наукові дослідження. На жаль, але серед студентів і навіть серед здобувачів наукових ступенів багато осіб, які не навчені займатись науковими дослідженнями, що штовхає багатьох до різних видів порушень академічної доброчесності, таких як: фабрикації, фальсифікації, списування, обман, хабарництво, необ'єктивне оцінювання тощо. Також у закладах вищої освіти є проблема інформування учасників освітнього процесу щодо правил академічної доброчесності. Як показують наші дослідження, близько $65 \%$ студентів - майбутніх бакалаврів закладів вищої освіти Одеси взагалі не знають, що таке академічна доброчесність. Водночас лише 20\% студентів дізнались про принципи академічної доброчесності від науково-педагогічних працівників.

Серед чинників та обставин об'єктивно-суб'єктивного характеру, які лише певною мірою залежать від конкретного учасника освітнього процесу, ми вважаємо необхідним визначити неналежний контроль керівниками та органами управління ЗВО за дотриманням норм академічної доброчесності. Без належної уваги та контролю керівництва доброчесність під впливом багатьох факторів буде порушуватись та іiі місце займе академічна недоброчесність. Н. Янош влучно зауважив, що керівник - не гід, не екскурсовод, не водій автобуса, він управляє людьми і його головною якістю $\epsilon$ не ввічливість, терпляча поблажлива ласкавість, а рішучість [5, с. 516]. Професор психології Ден Аріелі, завдяки багатьом експериментам, присвяченим поведінці людей, у своїх дослідженнях стверджує, що коли особі просто нагадують про етичні стандарти, вона зменшує нечесну поведінку та поводиться більш гідно. Тобто постійне нагадування про принципи та правила академічної доброчесності можуть поліпшити моральну поведінку учасників освітнього процесу. Наприклад, у Пристонському університеті, який з 1893 року має строгу системи честі, кожний першокурсник отримує примірник Конституції кодексу честі та лист про кодекс від Комітету честі, які він повинен підписати, перш ніж почне навчання. На першому тижні навчання першокурсники також обов'язково відвідують зустрічі, де обговорюють Кодекс 3 кураторами їхніх колегіумів. На додаток один 3 музичних університетських гуртів виконує для першокурсників свою «Пісню про кодекс честі». Також протягом навчання у Пристоні студентам систематично нагадують про Кодекс честі: вони підписуються під кожним завданням, яке здають («Цей документ - це моя робота, яка відповідає правилам Університету»). Перед кожним іспитом, тестом або контрольною роботою вони підписують ще одну додаткову заяву («Я заявляю, що вчинив чесно і не порушив Кодексу честі під час цього екзамену»). Також вони двічі на рік отримують електронні листи від Комітету честі. Професор Ден Аріелі також наголошує на важливості недопущення та уникнення саме першого акту нечесності. Тобто перший акт обману учасниками освітнього процесу збільшує ймовірність того, що за ним будуть і наступні аморальні дії. I, навпаки, робота щодо попередження першого порушення академічної доброчесності дасть змогу скоротити кількість порушень та зробити освітній процес закладу вищої освіти більш чесним та менш корумпованим. Томас Джефферсон зазначав, що «хто дозволить собі збрехати раз, той зробить це значно легше вдруге і втретє, а з часом це стане звичкою» [1, с. 129]. За даними досліджень Дена Аріелі, нечесність також може бути соціально заразною [2, с. 45]. Тобто недоброчесність збільшується, коли ми спостерігаємо за поганою поведінкою тих, хто нас оточує. Наприклад, якщо член нашої кафедри є авторитетною особою, яку ми поважаємо, $\epsilon$ ще більша ймовірність, що ми піддамося впливові.

Висновки і перспективи подальших розробок у цьому напрямі. Треба зазначити, що кожна причина правопорушень академічної доброчесності є складним явищем та потребує більш детального вивчення як окремо, так і у взаємодії 3 іншими. Також не менш актуальними та необхідними, на наш погляд, $є$ подальші дослідження, присвячені питанням усунення причин правопорушень академічної доброчесності у закладах вищої освіти та визначення ролі кожного суб'єкта освітніх відносин у цьому процесі. Важливим, на наш погляд, $є$ також вивчення закордонного досвіду роботи закладів вищої освіти щодо створення умов для ефективної реалізації принципів академічної доброчесності серед учасників освітнього процесу.

\section{ЛIТЕРАТУРА}

1. Анатомія брехні: колишні офіцери ЦРУ навчать вас виявляти обман / Ф. Г’юстон та ін. ; пер. $з$ анг. М. Дубини. Харків : Віват, 2019. 208 с.

2. Аріелі Д. Чесно про (не) чесність / пер. $з$ англ. Д. Завалій. Львів : Видавництво Старого Лева. 2019. $288 \mathrm{c}$. 
3. Афоризми відомих українців / укл. Є.В. Вдовиченко. Харків : ТОВ «Видавництво Фоліо», 2017. $256 \mathrm{c.}$

4. Великий тлумачний словник сучасної української мови. / укл. О. Срошенко. Донецьк : ТОВ «Глорія Трейд», 2012. 864 с.

5. Мудрость тысячелетий от А до Я. Великие мысли и афоризмы великих людей / авт.-сост. В.Н. Зубков. Москва : АСТ: Астрель, 2010. 861 с.

6. Подласый И.П. Педагогика: в 3-х кн. Общие основы : учебник для вузов. Москва : Гуманитар. изд. Центр ВЛАДОС, 2007. 527 с.

7. Про освіту : Закон України від 05 вересня 2017 р № 2145-VIII: URL: https://zakon.rada.gov.ua/laws/ show/2145-19 (дата звернення: 19.01.2021).

8. Скакун О.Ф. Теорія права і держави : підручник Київ : Алерта, 2011. 524 с.

\section{REFERENCES}

1. Houston, P. (2019). Anatomiia brekhni: kolyshni ofitsery TsRU navchat vas vyiavliaty obman [Spy the Lie: Forner CIA Officers Teach You How to Detect Deception]. (M. Dubyny, Trans.). Kharkiv : Vivat [in Ukrainian].

2. Arieli, D. (2019). Chesno pro (ne) chesnist [The (Honest) about Dishonesty]. (D. Zavalii, Trans.) Lviv : Vydavnytstvo Staroho Leva [in Ukrainian].

3. Vdovychenko, Ye.V. (2017) Aforyzmy vidomykh ukraintsiv [Aphorisms of famous Ukrainians]. Kharkiv : TOV "Vydavnytstvo Folio" [in Ukrainian].

4. Ieroshenko, O. (2012). Velykyi tlumachnyi slovnyk suchasnoi ukrainskoi movy [Large explanatory dictionary of the modern Ukrainian language]. Donetsk : TOV "Hloriia Treid" [in Ukrainian].

5. Zubkov, V.N. (2010). Mudrost tysyacheletyi ot A do Ya. Velykye mysly i aforyzmy velykykh liudei [The wisdom of millennia from A to Z. Great thoughts and aphorisms of great people]. Moskva : AST: Astrel [in Russian].

6. Podlasyj, I.P. (2007). Pedagogika [Pedagogika]. Moskva : Gumanitar. izd. Centr VLADOS [in Russian].

7. Law of Ukraine "On education" No. 2145-VIII, 2017, September 5. URL: https://zakon.rada.gov.ua/laws/ show/2145-19 [in Ukrainian].

8. Skakun, O.F. (2011). Teoria prava i derzhavy [Theory of law and the state]. Kyiv : Alerta [in Ukrainian]. 